\title{
A NOTE ON SOURCES AND CITATIONS
}

I have made liberal use of Nietzsche's unpublished notes, lectures, and essays, his juvenalia, and his personal correspondence. Unfortunately, adequate English translations of most of this material do not exist. These writings constitute an invaluable source of information on the development and continuity of Nietzsche's project. Nevertheless, the extensive use of material Nietzsche did not come to publish may appear in need of further justification. Certainly its importance vis-à-vis the books Nietzsche prepared for publication or published himself is moot. In this question I believe we must turn to Nietzsche's own understanding of the philosopher as one whose every scribble and handshake allows a semiotics of his soul. This does not do away with the problem of deciding the worth and context of Nietzsche's unpublished writings, but it does offer a prima facie legitimation of their use.

The Walter Kaufmann and R. J. Hollingdale translations of all of Nietzsche's major works have been used whenever possible (along with Marianne Cowan's translation of his early essay Philosophy in the Tragic Age of the Greeks). All citations are given within the text; titles are abbreviated and followed by page numbers. References to Nietzsche's notes, lectures, and essays (apart from those notes posthumously collected under the title The Will to Power) are taken from the Musarion edition of the Gesammelte Werke, are also given within the text, and are signified by $G W$ followed by volume and page number (for example, GW 14:224 means volume 14, page 224 of the Gesammelte Werke). Der Werdende Nietzsche, a compilation of the young 


\section{A NOTE ON SOURCES}

Nietzsche's autobiographical sketches, is also referred to by abbreviation and page number. All references to Nietzsche's personal correspondence are taken from Nietzsche Briefwechsel, Kritische Gesamtausgabe; the abbreviated title is followed by the date the letter or draft was written (for example, NB 18.4.74 means Nietzsche's letter of April 18,1874 , as taken from Nietzsche Briefwechsel). All translations from German sources are my own. A list of abbreviations and corresponding texts follows.

$\begin{array}{ll}\text { A } & \text { The Anti-Christ } \\ B G E & \text { Beyond Good and Evil } \\ B T & \text { The Birth of Tragedy } \\ \text { CW } & \text { The Case of Wagner } \\ D & \text { Daybreak } \\ \text { DD } & \text { Dithyrambs of Dionysus } \\ D W N & \text { Der Werdende Nietzsche } \\ \text { EH } & \text { Ecce Homo } \\ \text { GM } & \text { On the Genealogy of Morals } \\ \text { GS } & \text { The Gay Science } \\ \text { GW } & \text { Gesammelte Werke } \\ \text { HH } & \text { Human, All Too Human } \\ \text { NB } & \text { Nietzsche Briefwechsel } \\ \text { NCW } & \text { Nietzsche contra Wagner } \\ \text { PTG } & \text { Philosophy in the Tragic Age of the Greeks } \\ \text { TI } & \text { Twilight of the Idols } \\ \text { UM } & \text { Untimely Meditations } \\ \text { WP } & \text { The Will to Power } \\ Z & \text { Thus Spoke Zarathustra }\end{array}$

